Bojan Žalec

\title{
Liberalna evgenika kot uničevalka temeljev morale: Habermasova kritika ${ }^{1}$
}

\section{Liberal Eugenics as a Destroyer of the Foundations of Morality: Habermas' Critique}

Povz̧etek: Tema članka je liberalna evgenika in njena sprejemljivost z etičnega in moralnega vidika. S tem vprašanjem se je prodorno in odmevno ukvarjal Jürgen Habermas. Avtor predstavi njegove pomisleke in ugovore proti liberalni evgeniki. Habermas liberalno evgeniko opredeli kot prakso, ki posege v genom zarodka prepušča presoji staršev. Zanimajo ga moralne posledice takšnih posegov. Glavna nevarnost je uničenje vzajemnega priznavanja članov družbe kot avtonomnih in odgovornih delovalcev, ki so si v obeh omenjenih pogledih enakovredni. To priznavanje pa je sam temelj naše moderne zahodne moralne slovnice. Habermas v tem kontekstu opozori na pomen razvijanja etike vrste, ki posreduje med moralo in etiko. Središčni pojem njegove etike vrste je zmožnost, biti avtentičen (zmožnost biti to, kar sem, nem. Selbstseinkönnen). V tem pogledu se naveže na Kierkegaardovo pometafizično etiko sebstva. Avtor v članku opozori še na druge vire Habermasove misli, pojasni relevantne pojmovne distinkcije ter izlušči in premisli Habermasove glavne ugovore. Ti ugovori so: 1. liberalnoevgenični posegi mentalno načnejo poseganca, njegovo zavest o sebi kot avtonomnem, odgovornem in enakovrednem subjektu; 2. pravica in odgovornost, biti avtor svojega lastnega življenja, pripadata samo osebi sami; 3. ne moremo vnaprej vedeti, kaj je dobro za osebo; 4. poseganec mora imeti možnost reči: »Ne! « Avtor sklene z ugotovitvijo, da prenatalni genetski posegi ne smejo biti prepuščeni (samo)volji posameznikov, ampak se mora to vprašanje zakonsko urejati na podlagi javne razprave, v kateri lahko sodelujejo vsi člani družbe.

Ključne besede: liberalna evgenika, Jürgen Habermas, etika vrste, avtentičnost, avtonomnost, odgovornost, enakovrednost, ogroženost temeljev moralne slovnice zahodne družbe

1 Članek je nastal v okviru raziskovalnega programa Etično-religiozni temelji in perspektive družbe ter religiologija v kontekstu sodobne edukacije in nasilje (P6-0269) in temeljnih raziskovalnih projektov Vračanje religioznega $v$ postmoderni misli kot izziv za teologijo (J6-7325), Oživljanje kozmične pravičnosti: poetika feminilnega (J6-8265) in Medreligijski dialog - temelj za sožitje različnosti v luči migracij in begunske krize (J6-9393). Program in projekte je finančno podprla Javna agencija za raziskovalno dejavnost Republike Slovenije (ARRS). 
Abstract: The topic of the article is liberal eugenics and its acceptability from the ethical and moral point of view. Jürgen Habermas has dealt with this issue penetratingly and resoundingly. The author presents his concerns and objections towards liberal eugenics. Habermas defines liberal eugenics as a practice that leaves encroachments on the genome of an embryo to the discretion of parents. He is interested in the moral consequences of such interventions. The main danger is the destruction of the reciprocal recognition of members of society as autonomous and responsible agents who are equal in both of these respects. This recognition, however, is the very foundation of our modern Western moral grammar. In this context, Habermas points to the importance of developing species ethics that mediates between morality and ethics. The central notion of his species ethics is the ability to be authentic (the ability to be oneself, Ger. Selbstseinkönnen). In this respect, he refers to Kierkegaard's postmetaphysical ethics of the self. The author draws attention to other sources of Habermas' thought, explains relevant conceptual distinctions, and shells out and reflects on Habermas' main objections. They are as follows: 1. liberally eugenic interventions mentally eat away the person being subjected to them, their awareness of themselves as an autonomous, responsible and equal subject; 2. the right and responsibility to be the author of one's own life belong to the person alone; 3 . we cannot know in advance what is good for a person; 4. the person must be given a possibility to say »No!«. In conclusion, the author establishes that prenatal genetic interventions should not be left to (arbitrary) will of individuals, but that this issue should be regulated by law preceded by a public debate in which all members of society can participate.

Keywords: liberal eugenics, Jürgen Habermas, species ethics, authenticity, autonomy, responsibility, equality, jeopardy of the foundations of the moral grammar of Western society

\section{Uvod}

Jürgen Habermas se je prodorno ukvarjal z vprašanjem, kakšne posledice ima lahko poseganje $v$ genetski segment ljudi. Zanimajo ga predvsem moralne posledice. Njegova središčna ugotovitev je, da takšni posegi lahko zamajejo ali celo spodkopljejo same temelje naše morale: ta morala temelji na univerzalni enakosti avtonomnih oseb, ki se vzajemno priznavajo kot takšne. To je v bistvu kantovsko moralno stališče, ki ga sprejema tudi sam Habermas in za katero trdi, da je tudi sprejeto moralno stališče sodobne pluralistične družbe. Habermas premišlja o primerih, ko bi starši spremenili genetski segment svojih otrok tako, da bi bili ti otroci bolj sposobni za nekatere stvari na račun sposobnosti za druge stvari. Na primer, da bi bili bolj sposobni v matematičnem smislu na račun atletskih sposobnosti. Toda s tem poskušamo samo nekako z zgledom ilustrirati, o čem govorimo. Govorimo o tem, da starši že pred rojstvom otrok posežejo v genetski segment svojih otrok in 
ga spremenijo v skladu s svojimi željami, češ da hočejo najboljše za svojega otroka. Ti posegi nepovratno določijo otroka. To, kar Habermasa skrbi pri takšnih posegih, je možnost, da bi lahko tako učinkovali na otroka, da bi se mentalno ne mogel več dojemati kot oseba, v pogledu avtonomnosti enakovredna tistim ljudem, ki niso bili podvrženi takšnim posegom. Ne govorimo o tem, da bi takšna oseba izgubila pravice, da bi ji bile kratene pravice, ampak o mentalnih posledicah za takšno osebo. Če se nekdo ne čuti več enakovrednega drugim v pogledu avtonomnosti, potem to lahko postavi pod vprašaj tudi njegov pogled na osebno odgovornost, ker je avtonomnost osebe temelj njene odgovornosti. Osebe, ki so avtonomne in odgovorne in ki se vzajemno kot takšne pripoznavajo, so temelj naše moralne skupnosti in njene moralne slovnice. Posegi v genetski material osebe brez kakršnegakoli njenega pristanka lahko usodno ogrozijo same temelje te slovnice. Po Habermasu gre za posebno vrsto paternalizma (Habermas 2005, 71), ki je nezdružljiv z obravnavo človeka, ki je predmet genetskih posegov, kot avtonomne osebe. Obravnava človeka kot osebe pomeni, da tako korenite in nepovratne posege $v$ njegovo bitje lahko storimo samo z njegovim pristankom. Habermas poudarja, kako smo seveda dolžni storiti vse, da nekega človeka obvarujemo pred trpljenjem, vendar pa takrat, ko takim posegom on sam nasprotuje, to ni zaščita pred trpljenjem.

\section{Pomembne distinkcije}

V razpravi Habarmas uporablja kar nekaj distinkcij, upoštevanje katerih je zelo pomembno za pravilno razumevanje njegovega stališča. Prva je razlika med nastalim ali samoraslim in narejenim. (Habermas 2005, 53-61) Po Habermasovih domnevah je duševnost človek takšna, da mora njegova genetska zasnova ostati nedotaknjena, če to ni povezano z očitnimi preprečitvami trpljenja ali hendikepiranosti zaradi genetskih okvar; $v$ tem smislu mora biti samorasla, ne narejena, da se lahko človek sam dojema kot osebo, ki je po avtonomnosti enakovredna drugim, tudi samoraslim osebam. Samoraslost je potrebni pogoj, iz duševnih razlogov, da se lahko človek dojema kot avtonomna oseba. Habermas v tej točki razmišlja tudi o možnosti, da človeku ne bi povedali o posegih v njegov genetski segment. To možnost zavrne kot neke vrste prevaro oziroma kot nekaj, kar je ponovno v nasprotju z obravnavo osebe kot avtonomne. To možnost primerja s tem, da osebi ne povemo resnice o njenih (bioloških) starših.

Naslednji pomembni pojmovni par sta moralizacija in tehnizacija človeške morale (Habermas 2005, 32-38). Ti posegi v genetiko človeka bi pomenili tehnizacijo človeške narave in opustitev njene moralizacije. Govorimo o tem, kako naša sedanja zahodna moralna slovnica zahteva, da na človeka ne gledamo samo kot na nekaj, kar je na voljo za naše oblikovanje, ampak je za našo moralno slovnico, za to, da naša moralna jezikovna igra lahko poteka, potrebna omejitev razpoložljivosti ljudi. Da človek ostane človek, da ohrani naravo človeka - to v okviru pometafizičnega mišljenja pomeni, da je človek obravnavan in pripoznan kot človek -, je potrebna omejitev razpoložljivosti človeka, ali drugače rečeno: moralizacija člo- 
veške narave. O tem, kdaj človek še ostane človek, ne more in ne sme odločati tehnika, ampak o tem odločajo zahteve oziroma implikacije naše moralne slovnice, to pa vključuje tudi zaščito pogojev, ki so potrebni, da naša moralna igra sploh lahko poteka. Zadevni posegi v genetiko človeka bi pomenili eliminacijo teh pogojev. Znašli bi se $v$ moralnem vakuumu, $v$ katerem ne bi mogli govoriti celo niti več o moralnem cinizmu, ker tudi ta cinizem še vedno pomeni neko navzočnost moralnega, tudi če na način zavračajočega odnosa do morale. To pa po Habermasu pomeni v vsakem primeru način življenja, ki ni dober. To je trditev, ki gre onkraj zavzemanja za ta ali oni način življenja. Glede tega filozofija v pometafizičnem obzorju lahko razpravlja samo na metaravneh oziroma z razmislekom o formalnih lastnostih, ne more pa se več zavzemati za ta ali oni konkretni način kot dobrega. To je po Habermasu pridobitev moderne, glede katere se večina strinja, da je nekaj pozitivnega. Filozofija lahko kaj pove o prednostih ali minusih konkretnih stališč o dobrem življenju samo na podlagi nevtralnih ugotovitev oziroma razlogov, ne pa v nenevtralnem, "pristranskem « diskurzu. Pri zavrnitvi življenja v moralnem vakuumu pa po Habermasu ne govorimo o kršitvi načela nevtralnosti, ampak o stališču, ki je nad ravnjo o izbiri med tem ali onim načinom življenja. Habermas meni, da je človek bitje, ki je takšne narave, da ne more dobro živeti v moralnem vakuumu oziroma da v njem izgubi človeško dostojanstvo. (80; Strahovnik 2017, 271-274) Lahko preneha biti človek in živi v moralnem vakuumu ali pa v njem živi slabo. Ne more pa kot človek v njem živeti dobro (Platovnjak 2017a).

To lahko dodatno razumemo v luči ugotovitve, da je stanje nihilizma, vrednotne izravnave vsega, za človeka psihološko nevzdržno in dejansko nemogoče. Človek je "obsojen « na neko izbiro, odločitev in (potemtakem) ravnanje. Tudi »neravnanje» ali popolna pasivnost je neka drža ali odločitev in ravnanje. Zato se nihilizem pogosto manifestira kot instrumentalizem oziroma se vanj preobrazi. (Žalec 2010, 32; 2011, 29; 2013, 58; 2015, 19-20). Tisto, kar Habermas imenuje moralni vakuum (Habermas 2005, 80), je pravzaprav stanje nihilizma. Iz tega lahko sklepamo, da bi tehnizacija oziroma demoralizacija človeške narave na način predrojstvenega poseganja v človekov genetski segment vodila v moralni vakuum in kot posledica tega $v$ instrumentalizem. ${ }^{2}$ Po Habermasovem mnenju bi odpoved moralizaciji človeške narave pomenila instrumentalizacijo človeške vrste, natančneje, kakor pravi Habermas, samoinstrumentalizacijo človeške vrste, saj bi človeška vrsta instrumentalizirala samo sebe. To pa je dober razlog, da tehnizacijo človeške narave zavrnemo.

Habermas na začetku razprave govori o vzdržni drži filozofije v pometafizični dobi in naredi razliko med praktično filozofijo, ki vključuje moralno teorijo in teorijo pravičnosti, na eni strani in etiko na drugi. Praktična filozofija se tudi danes nikakor ne odpoveduje nobenemu razmisleku o normativnosti, vendar se v glavnem omejuje na vprašanja pravičnosti. (Habermas 2005, 11) Sprašuje so o tem, kaj je v enakem interesu vsakogar in kaj je enako dobro za vse. Pri tem odmisli vidik prve osebe in abstrahira od konkretnih kontekstov. Etika pa ravna prav nasprotno. Pri njej so po-

2 Za podrobnejšo obravnavo psiholoških in moralnih vidikov instrumentalizma (v obliki makiavelizma) prim. Ibragimov et al. 2018. 
membne oblike eksistencialnega samorazumevanja. Zanima jo vprašanje, kaj je najbolje »zame« ali za »nas« v kontekstu moje oziroma naše partikularne življenjske zgodbe in edinstvene oblike življenja. Tesno je povezana z vprašanji identitete: kako moramo razumeti sami sebe, kdo smo in kdo bi radi bili. Očitno ni odgovorov na takšna vprašanja, ki bi bili neodvisni od konkretnih kontekstov in bi tako zavezovali vse in vsakogar enako. Etika je partikularistična, praktična filozofija pa univerzalistična.

Filozofija v pometafizični dobi ne more več dajati neposrednih odgovorov na vprašanja etike. Zato se prav pri vprašanjih, ki so za nas najpomembnejša, omeji na metaraven in raziskuje samo formalne lastnosti procesov samorazumevanja, ne da bi zavzela to ali ono vsebinsko stališče. To nam po eni strani morda ni dovolj, toda po drugi strani: kako lahko danes utemeljeno ugovarjamo takšni vzdržnosti filozofije? (Habermas 2005, 11-12) Vendar pa je prav pri vprašanju liberalne evgenike, poljubne vzreje človeka oziroma poseganja v človeško bitje, treba vpeljati še neko drugo raven razmisleka: razmisliti moramo o tem, kakšna etika je potrebna na ravni vrste, kakšno eksistencialno samorazumevanje človeka kot človeka je potrebno, da lahko naša moralna igra deluje. Ker pa je sestavni del naše moralne igre razlikovanje med etiko in moralo, ${ }^{3}$ se mora takšna etika razlikovati od etik, ki so po Habermasu razni svetovni nazori, do katerih pa mora biti sodobna pluralistična družba na ravni morale nevtralna. Habermas je našel temeljni pojem te etike v pojmu Selbstseinkönnen, moči biti to, kar sem, moči biti sebstvo oziroma biti samost. Slovenska prevajalka se je odločila za prevod zmožnost biti-sam-svoj (61). Lahko bi, v duhu eksistencialistične tradicije, uporabili tudi izraze samolastnost, avtentičnost, pristnost.

Kakorkoli ga že poimenujemo, je ta ideal, drugače od vrlin in vrednot, ki jih zagovarjajo posamezni svetovni nazori, formalne narave, saj ga lahko apliciramo na vsak življenjski projekt, se pravi, tudi na projekte, ki so si vsebinsko popolnoma različni. (Junker-Kenny 2011, 124) Ta pojem povezuje raven etike z ravnjo morale. Etike se dotika, kolikor govori o tem, kaj je dobro, morale pa, ker ga naša morala predpostavlja in ker moralna družba mora, po modernem gledanju, vsakemu človeku omogočiti, da je to, kar je, oziroma da postane sam svoj v gornjem smislu. Habermas ukvarjanje s to vmesno oziroma povezovalno ravnjo imenuje etika vrste, tako da lahko rečemo: središčni pojem njegove etike vrste je pojem samolastnosti. Ker vrstna etika, temelječa na tem pojmu, ne spodkopava moderne razlike med dobrim in pravičnim in ker tesno zadeva moralo, se tudi filozofija v (post) moderni lahko ukvarja z njo in se hkrati tudi mora ukvarjati.

Kjer je pomembno vprašanje dobrega življenja za (konkretnega) posameznika, tam je veliko prostora za pristop veleblagovnice s široko ponudbo oblik dobrega življenja in posameznik ima zelo širok okvir svobode, da sam izbere to ali ono obliko (Malović 2015, 953). Pri vprašanju o sprejemljivosti liberalne evgenike pa v

3 " 'Moralna imenujem tista vprašanja, ki zadevajo pravično skupno življenje. " (Habermas 2005, 47) Ob tem lahko dodamo, da v sedanji, tehnološki dobi vse bolj v ospredje stopa pereč problem medgeneracijske pravičnosti, za katerega šele iščemo pravo rešitev. Tega se globoko zaveda tudi Cerkev: „Papež Frančišek obžaluje, da še nismo zadostno razvili kulture, ki bi pravično obravnavala vse rodove - pretekle, sedanje in prihodnje. Zato poziva k razvoju medgeneracijske pravičnosti. " (Petkovšek 2019, 25) Habermasov premislek o liberalni evgeniki tudi v tem pogledu pomeni pomemben prispevek. 
primerjavi z običajnimi etičnimi izbirami načina življenja obstajata vsaj dve pomembni razliki: 1. Izbira tega ali onega načina ali oblike življenja, te ali one etične možnosti, ne ruši temeljev naše moralne jezikovne igre. 2. Posamezniku je $v$ »veleblagovnici« ponujeno in on izbere, zato je vsaj formalno obravnavan kot avtonomna oseba. Pri predrojstvenem posegu v genetski material človeka pa ta človek ni nič vprašan za pristanek in torej ni obravnavan kot oseba. $V$ tej točki bi lahko kdo pripomnil, da pred rojstvom človek dejansko niti ni oseba. ${ }^{4}$ Habermas opozarja, da ni treba človeka imeti za osebo, če hočemo zaščititi njegovo življenje. V tem smislu razločuje med človeškim dostojanstvom in dostojanstvom človeškega življenja. (Habermas 2005, 38-47) Ni treba, da ima človek (že) dostojanstvo osebe, to je: človeško dostojanstvo, da bi njegovo življenje imelo dostojanstvo.

Naj na tej točki dodamo nekaj pojasnil o Habermasovem pometafizičnem stališču. Po tem neobjektivističnem stališču ljudem ne pripadajo človekovo dostojanstvo in podobne stvari same po sebi, ampak so stvar pripoznavanja, natančneje, vzajemnega pripoznavanja med ljudmi. Pometafizično stališče ne govori več o stvareh "na sebi«, ampak stvari zanj »obstajajo« oziroma veljajo (kot takšne in takšne) toliko, kolikor se dejansko (kot takšne in takšne) pripoznavajo v odnosih med ljudmi. Imeti dostojanstvo in biti obravnavan v neki družbi oziroma skupnosti, kakor da ga imaš, je za to stališče dejansko isto. Zato morajo biti stvari, da obstajajo za pometafizično stališče, urejene z normami, zakoni, institucijami ipd. neke družbe. To je heglovski element Habermasovega stališča. Dejanska morala ne obstaja neodvisno od institucij in norm neke družbe, ampak je v njih utelešena. Dejanska morala je Sittlichkeit, nravnost v Heglovem smislu besede. Zato se je treba o moralnih zadevah odločati v javni družbeni razpravi. Samo takšne odločitve imajo moralno težo in legitimnost. Za takšno razpravo pa so potrebne avtonomne in odgovorne osebe, ki se vzajemno pripoznavajo kot takšne. Prav za obstoj takšnih oseb pa posegi v genetsko zasnovo ljudi pomenijo veliko grožnjo, če jih ne že kar onemogočajo. Zato so ti posegi velika nevarnost uničenja samih temeljev nravnosti naše družbe. Ob tem zgledu se spet potrjuje stara ugotovitev, da liberalna demokracija sama ne more zagotavljati pogojev svojega lastnega obstoja. Ti pogoji so predpolitične narave. (Böckenförde 1976, 60; Habermas \& Ratzinger 2005; Habermas 2007, 2-3; 77; Reder \& Schmidt 2010, 7; papež Janez Pavel II. 2005, 143-177; Žižek 2009, 76; Galston 2008, 315-353; Žalec 2008, 447-462; Žalec 2009, 340-341, op. 5; Žalec 2010, 195-196)

\section{Biti sam svoj (avtentičnost)}

Biti sam svoj v zgoraj orisanem smislu je eden središčnih pojmov eksistencialne misli. Dejansko Habermas svojo razpravo o prihodnosti človeške narave začne z razmislekom o Kierkegaardu. Označi ga za pometafizičnega misleca in prvega pometafizičnega etika. Da je bil Kierkegaard pometafizični etik, se lahko strinjamo, saj svojih pogledov ni več utemeljeval metafizično, ampak je bil slovničar krščanske vere (Roberts 1995, 151ff; Žalec 2018b, 195-198), ki se je zavedal, da vere ni mogoče doka-

4 Za predstavitev različnih stališč o statusu osebe gl. Globokar 2016, predvsem 325-328. 
zati, še več, menil je, da je njeno dokazovanje v nasprotju z jezikovno igro vere. $\mathrm{V}$ tem pogledu njegovo stališče sovpada z Wittgensteinovim (Žalec 2018a, 51). Kljub temu da je bil Kierkegaard že pometafizični mislec, ni bil poreligiozni mislec. Vendar pa je mogoče Kierkegaarda ne glede na to uporabiti tudi pometafizično, saj je dovolj formalen in dovolj nemetafizičen. Kierkegaard svojega bralca ni več »pridobival« z metafizičnim dokazovanjem, ampak s fenomenološkimi in psihološkimi prijemi.

Kierkegaard je bil po Habermasovem mnenju prvi, ki je na temeljno etično vprašanje o uspehu in neuspehu svojega lastnega življenja odgovoril s pometafizičnim pojmom biti samost. (Habermas 2005,13 ) Kljub temu da je na vprašanje o pravilnem življenju dal resda pometafizičen, toda hkrati globoko religiozen in teološki odgovor, so tudi filozofi, zavezani metodičnemu ateizmu, v njem prepoznali misleca, ki izvirno obnavlja temeljno etično vprašanje in nanj odgovarja po eni strani »substancionalno« oziroma vsebinsko, v nasprotju z več kakor problematično »praznostjo« Kantove etike, po drugi strani pa kljub temu vendarle tudi dovolj formalno, da je lahko $v$ tem pogledu sprejemljiv za legitimni moderni svetovnonazorski pluralizem, ki v izvorno etičnih vprašanjih prepoveduje kakršenkoli paternalizem oziroma "varuštvou. (13)

Kierkegaard je soočenje etičnega in estetičnega življenjskega nazora predstavil kot izbiro na način ali - ali. (13) Kontrast hedonizmu predstavlja etični način življenja, ki od posameznika zahteva, da izbere samega sebe in se reši odvisnosti od premočnega okolja. (14) Posameznik se mora dokopati do zavesti o svoji individualnosti in svobodi. Tako se vrne iz razpršenosti in njegovo življenje (lahko) dobi transparentnost in kontinuiteto. Takšna oseba lahko prevzame odgovornost za svoja lastna dejanja in odgovornost do drugih. Človek, ki tako ozavesti samega sebe, postane sam cilj svojega ravnanja, toda ne samovoljno določen, ker ima sebe kot svojo zadolžitev, pred katero stoji, čeprav je postala njegova tako oziroma s tem, da jo je sam izbral. (Kierkegaard 2003, 509) Kierkegaardova pozornost je usmerjena na strukturo biti samost, ki je oblika etične samorefleksije in izbire samega sebe in ki jo določa »neskončni« interes za uspeh osebnega življenjskega načrta. »Posameznik samokritično osvoji preteklost svoje življenjske zgodovine, na katero je dejansko naletel in jo konkretno posedanjil glede na prihodnje možnosti delovanja. « (Habermas 2005, 14) Šele tako naredi iz sebe nenadomestljivo osebo in nezamenljivega posameznika. Z moralno strogim vrednotenjem in s kritično prisvojitvijo dejanske zgodbe se konstituira kot oseba, kakršna hkrati je in bi rad bil. (15) Vse, kar je postavljeno z njegovo svobodo, mu bistveno pripada, naj je videti še tako naključno. Čeprav je sam svoj »urednik», to ni samovolja, saj se zaveda, da je osebno odgovoren za red stvari, v katerem živi, odgovoren pred Bogom. (Kierkegaard 2003, 507-508) Etično obliko, ki se poraja iz osebne sile, je mogoče stabilizirati samo v odnosu do Boga. (Habermas 2005, 15; Kondrla in Pavlíková 2016, 110; Valčo 2016, 101; Králik in Torok 2016, 72-73; Binetti in Pavlíková 2019; Máhrik 2018; Valčo in Peter Šturák. 2018; Tavilla, Králik, Webb, Jiang in Aguilar 2019; Tavilla, Králik in Roubalová 2019) ${ }^{5}$

5 Branko Klun je to Kierkegaardovo stališče prikazal takole: »Pomembna je ıgradnjar samega sebe: nisem samozadostni in vase zaprti sjaz samı, temveč sem utemeljen v odnosu do presežnosti, ki me omogoča, ki omogoča moj pristni jaz.« (Klun 2013, 373) 
Kierkegaard je menil: dokler moralo, ki daje merilo za raziskovanje samega sebe, utemeljujemo samo na človeškem spoznanju, manjka motivacija za prenos moralnih sodb v prakso. ${ }^{6}$ Boril se je proti intelektualističnemu razumevanju morale. Če bi morala lahko samo z dobrimi razlogi gibala voljo spoznavajočega subjekta, ne bi bilo mogoče pojasniti tistega stanja opustošenosti, ki ga je Kierkegaard, kritik svojega časa, vedno znova grajal - stanja krščansko poučene, "razsvetljene», a globoko skvarjene družbe. (Habermas 2005, 15) Na jok in na smeh gre človeku, je zapisal Kierkegaard, ko vidi, da vse to znanje in razumevanje nimata nobenega vpliva na življenje ljudi. (Kierkegaard 1987, 80) Ali, če navedemo Habermasove besede, ko povzame Kierkegaarda:

»V normalnost strnjena potlačitev ali cinično priznanje nepravičnega stanja sveta ne govorita o pomanjkanju znanja, ampak o korupciji volje. Ljudje, ki bi lahko vedeli bolje, nočejo razumeti. Zato Kierkegaard ne govori o krivdi, temveč o grehu.« (Habermas 2005, 16)

Toda vrnimo se k zgoraj omenjenemu biti-sam-svoj. Neka določena mera te svojosti je potrebna, da se ima človek lahko za avtonomno osebo in potemtakem za obstoj moderne moralnosti. $V$ tem je relevantnost eksistencialistične misli in njenega zagovarjanja pomena avtentičnosti oziroma samolastnosti za razprave v sodobnem kontekstu (bio)tehnološke družbe. V tem vidimo tudi nov pomen neskvarjene kulture in ideala avtentičnosti, katere nemara najbolj opazen zagovor je v zadnjih desetletjih predložil Charles Taylor (Taylor 2000; Žalec 2019). ${ }^{7}$ Vsekakor pa lahko vprašanje oziroma problem - ali vsaj del tega problema, ki ga je Habermas predstavil v zvezi s prenatalnimi posegi v genetiko človeka -, v eksistencialistični terminologiji izrazimo takole: ali človek še lahko pristno biva, ali je še lahko sam svoj, če smo pred njegovim rojstvom posegli v njegov genski segment, da bi ga naredili primernejšega za neke določene naloge. Sartre bi nedvomno moral odgovoriti z ne, kajti prav zaradi možnosti pristnega bivanja je zavrnil vsakršno vnaprejšnje določanje, oblikovanje ali »programiranje« človeka, saj je to nezdružljivo s pristnim bivanjem. (Sartre 1968, 186-189; 194; 212-213) Vsekakor pa je po Habermasu s takšnimi prenatalnimi posegi ta možnost za poseganca (»programirano« osebo) močno ogrožena, če ne že kar blokirana.

\section{Glavni ugovori proti liberalni evgeniki}

Habermas to svojo trditev oziroma zaskrbljenost pojasni oziroma utemelji z več razlogi. Izrazi in predloži tudi veliko domnev in svojih lastnih intuicij, ki jih drugače $v$ večji ali manjši meri poskuša pojasniti in nekako utemeljiti. Nekatere od njih bi bilo možno vsaj delno ali dodatno tudi empirično podkrepiti, verificirati ali preveriti. Toda tudi če so samo intuicije, nam dajejo neko določeno razumevanje o tem,

6 Za podrobnejšo obravnavo Kierkegaardovega razumevanja motivacije z moralnega vidika prim. Martín, Ortiz-Cobo in Kondrla 2019.

7 O pomembnosti kulture za človekovo celostno življenje gl. Platovnjak 2017b. 
zakaj se ljudje bojijo genetskih posegov, česa jih je strah. Odgovor je, da se (intuitivno) bojijo prav tega, o čemer govori Habermas: ukinitve človeka kot avtonomnega in odgovornega bitja, ukinitve te univerzalne enakosti med ljudmi in kot posledica tega sesutja solidarnosti, ki temelji na teh podlagah, in celotne naše moralne igre, na kratko, sesutja naše morale. In to bi tudi moralo biti naše vodilo pri postavljanju določnejših in konkretnejših meril in omejitev za genetske raziskave in posege: samo tisti posegi in raziskave, ki ne ogrožajo naše morale, temelječe na univerzalni enakosti ljudi kot avtonomnih in odgovornih subjektov in na tej enakosti zgrajene univerzalne solidarnosti med njimi, samo tisti posegi in raziskave so sprejemljivi. Pravzaprav sta Habermasova metoda in merilo zelo preprosta: prenatalne posege v genetiko človeka ocenjuje $z$ vidika sprejemljivosti in posledic s stališča njegove kantovsko-heglovske pometafizične komunikativne etike oziroma morale, katere središčne vrednote so svoboda, enakost in solidarnost. To so njegove glavne vrednote. Išče načine za njihovo času primerno razumevanje, določitev, uresničevanje (implementacijo) in zaščito. Te vrednote so merilo njegovega presojanja in vrednotenja. To so vrednote moderne, ki še niso bile zadovoljivo uresničene (Habermas govori o nedokončani moderni (Habermas 2003)) in jih je treba zaščititi pred vsakršnimi verskimi fundamentalizmi ali scientističnimi oziroma evgeničnimi pobudami. Na njih temelji tudi njegova kritika liberalne evgenike. Sestavna dela svobode sta avtonomija in samoopredelitev, integralni moment enakosti pa je vzajemno, recipročno razmerje med subjekti. (Pagon 2005, 129)

Kakor smo že omenili, Habermas za svojo zaskrbljenost glede liberalne evgenike navaja več razlogov in pojasnil. Njegovo razpravljanje je zelo vseobsegajoče, bogato, večplastno, po drugi strani pa izredno zgoščeno in pomensko nabito in tudi večpomensko. Zato je njegovo misel težko povzemati. Kljub temu pa menimo, da lahko izluščimo štiri glavne razloge oziroma ugovore, zaradi katerih nasprotuje prenatalnim genetskim posegom (kot negativnim dejavnikom naše moralne oziroma politične (demokratične) slovnice), ki pa so med seboj tesno povezani in prepleteni:

1. Posegi mentalno načnejo poseganca, njegovo zavest o sebi kot avtonomnem, odgovornem in enakovrednem subjektu. (Habermas 2005, 84; 87; 97; 99)

2. Pravica in odgovornost za avtorsko oblikovanje svojega lastnega življenja pripadata samo osebi sami (tako imenovani argument tuje določitve). (91ff, 100)

3. Mi ne moremo vedeti vnaprej, kaj je dobro za osebo. $(94 ; 95)$

4. Poseganec mora imeti možnost reči: »Ne!« (95)

V svojem nasprotovanju tem posegom v genetiko nerojenih se Habermas naveže na dve ugotovitvi Hannah Arendt (66-67). Prva je, da človek biva kot človek šele skozi interakcijo z drugimi ljudmi in z vključenostjo v (politično) skupnost (Arendt 1996, 10; 2003, 387-384; Habermas 2005, op. 44; Žalec 2018c, 207-209; 211-218; 222-223). Drugo je njeno poudarjanje pomena novega začetka (Arendt 1996, 11; 2003, 562; 570; 576; ; Žalec 2018c, 216). Tudi Habermas opozarja na pomen tega,

8 "Začetek, še preden postane zgodovinski dogodek, je vrhovna sposobnost človeka; politično je identičen s človekovo svobodo. Initium ut esset homo creatus est - >da bi prišlo do začetka, je bil ustvarjen človekı, je rekel Avguštin (De Civitate Dei, 12. knjiga, 20. poglavje). Ta začetek zagotavlja vsako novo rojstvo; v resnici gre za vsakega človeka." (Arendt 2003, 576) 
da človek (lahko) začne nekaj povsem novega (Habermas 2005, 66-67). Da je njegov začetek lahko res pravi začetek, mora biti nerazpoložljiv in vanj ne sme posegati nobena druga oseba. Habermas je zapisal, da čutiti se svobodnega najprej pomeni, moči začeti nekaj novega. $(2007,142)$ Kjer govorimo o človeku kot človeku, tam mora biti možnost takšnega novega začetka zanj. Pri prenatalnih genetskih posegih bi težko govorili o človekovem rojstvu kot nerazpoložljivem začetku.

Objektiviranje naravnega okolja pospešuje v notranjosti subjekta samoobjektiviranje. Obstaja dialektična sovisnost med obvladovanjem narave in razpadom subjekta. (153) Zunanja narava, ki je bila narejena razpoložljivo, je po Habermasu embrionalno telo neke prihodnje osebe, razpadajoča subjektivna narava pa »organizem, razvit iz embria, ki ga naraščajna oseba izkusi kot svojo prenatalno obravnavano telesnost « (ibid.). Vendar si posameznik lahko pripiše svoja »dejanja« samo »tedaj, če se s telesom identificira kot s svojo lastno telesnostjo. Drugače manjka nanašalna baza za izvorno intimno seznanjenost s seboj kot odgovornim avtorjem lastnih ravnanj." (ibid.) S prenatalnimi posegi v organizem, v telo nerojenega človeka "se v sfero vsakič lastne telesnosti usidra tuja volja in omaja nanašalno bazo za samopripisovanje iniciative in lastnega načina življenja (154). S takšnimi posegi, ki bi jih lahko vodili najboljši nameni staršev, bi starši sami sebe naredili »za soavtorje življenjskih zgodb svojih otrok«. To pa bi poškodovalo otrokovo zavest osebne svobode, »ki je vezana na praktično nerazpoložljivost subjektivne narave« (154).

Če se "programirana« oseba pozneje ne bi strinjala s posegi svojih staršev, bi se zgodilo tole: ne samo da bi starše (lahko) klicala na odgovornost, ampak bi njihovo intervencijo čutila kot izredno veliko, temeljno in globinsko kršitev svoje lastne svobode: »Iz perspektive prizadetega se starši prikazujejo kot nenaprošeni soavtorji življenjske zgodbe, za katero pa mora vsakdo, da bi se v ravnanju čutil svobodnega, pretendirati, da je sam edini avtor.« (153-154)

Habermas pravi, da so predrojstveni genetski posegi staršev »nedopustna predrznost«. (154) Za to je več razlogov. Prvič, to so z vidika vrednot in delovanja moderne, svetovnonazorsko pluralistične liberalno demokratične družbe, po kateri etična vprašanja sodijo v izključno domeno oziroma pristojnost samega posameznika. Poleg tega ti posegi spodkopavajo delovanje te družbe, kajti uničujejo zavest o svoji lastni avtonomnosti, svobodnosti in (s tem) odgovornosti (za svoja ravnanja) pri »programiranih« osebah. Ta zavest je temeljnega pomena za delovanje moralne jezikovne igre sodobne družbe, ki se opira na to, da se njeni člani vzajemno pripoznavajo kot enaki, prav v pogledu, da so vsi avtonomni subjekti svobode. Programirane osebe brez te zavesti se ne bi mogle več imeti za enake neprogramiranim osebam s to zavestjo. (Habermas 2005, 84-85; Strahovnik 2018, 302-304) Ker pa je zavest o osebni avtonomnosti, svobodnosti in odgovornosti potrebni pogoj za to, da smo avtonomni, svobodni in odgovorni, jih za takšne in potemtakem enake ne bi mogli več imeti niti drugi. ${ }^{9}$

Glede tretje točke Habermas opozarja na primernost drže, ki jo je Hans Jonas imenoval »hevristika strahu«. (Jonas 1984, 26-27; Morris 2013, 18) V nasprotju

9 Glede etičnih implikacij koncepta človeka kot (ne)svobodnega bitja prim. Ambrozy, Kralik in Martín 2017. 
s to držo so prenatalne odločitve, ki imajo nepopravljive učinke, vedno "pametnjakarske« (Habermas 2005, 95), saj ne moremo zagotovo vedeti, ali bodo posegi res koristili posegancu, ali bodo res dobri zanj (90-91; 94-95). Pa tudi če kdaj morda vemo, kaj je potencialno dobro za drugega, mu lahko to posredujemo le v obliki kliničnih nasvetov za posege, na katere pa mora oseba pristati oziroma mora imeti možnost reči: »Ne!« (94-95). To pri predrojstvenih intervencijah ni mogoče. Vendar mora biti ta možnost človeku vsekakor dana. Za to sta dva razloga. Prvič, samo bitje, ki mu priznavamo pravico do tega, da reče: „Ne! «, dejansko obravnavamo kot osebo. Drugič pa zato, ker na področju etike ni možno objektivno spoznanje »in je v vse etično védenje vpisana perspektiva prve osebe« (95). ${ }^{10}$ Zato končni človeški um ne more dati odgovora, katera genetska dota je za drugega, pa tudi če je ta drugi naš otrok, najboljša.

\section{Terapija in negativna evgenika versus izboljšava (načrtovanje) in pozitivna evgenika}

Na tem mestu je treba reči še nekaj besed o razliki med terapevtsko držo in držo načrtovalca in o ločnici oziroma pragu med negativno in pozitivno evgeniko. Pri negativni evgeniki govorimo o terapiji oziroma kliničnem pristopu, katerega namen je, na primer, preprečitev trpljenja. Toda Habermas opozarja na evgenične prakse, »ki niso upravičene s kliničnimi nameni in ki - to je moja teza - skupaj z zavestjo avtonomije okrnijo tudi moralni status obravnavane osebe« (Habermas $2005,100)$. $V$ teh primerih govorimo o pozitivni evgeniki, pri kateri je pomembna izboljšava kakovosti človeka. Terapevt se lahko do živega bitja (na podlagi njegovega utemeljeno vnaprej postavljenega, tudi neizogibno protidejstvenega soglasja) vede, kakor da je to bitje že druga oseba; to bo nekoč postalo (torej tudi če zarodka še nima za osebo). Terapevtski drži nasprotna pa je drža načrtovalca. Načrtovalec ima do zarodka tako optimirajočo kakor instrumentalizirajočo držo: genetska sestava zarodka naj bi bila izboljšana na podlagi subjektivno izbranih meril oziroma v skladu z njimi. Habermas držo do prihodnje osebe, ki pa je že v embrionalni fazi obravnavana kot oseba, ki lahko reče da ali ne, imenuje performativna drža (101). Na njeno mesto stopi pri pozitivni evgeniki drža, ki cilj klasičnega rejca - izboljšati dedne značilnosti vrste - poveže z operacijskim načinom inženirja, da instrumentalno posega v skladu s svojim lastnim načrtom in obdeluje embrionalne celice kot material (ibid.). Habermasovo stališče je, da lahko posegamo v dedni segment (prihodnje) osebe samo, če imamo dobre razloge, da (protidejstveno) predpostavljamo njeno soglasje (če oziroma ko bi bil zarodek oseba in bi lahko presojal (za nazaj), potem bi dal pristanek za poseg). Drugače pa posegi niso dopustni. $\vee$ tej luči postavi osnovno merilo tudi za presojanje predimplementacijske diagnostike in raziskav človeških embrionalnih celic: ta kriterij nikakor ne utira poti držam, ki gredo vštric z »izboljševalnim« in postvarjevalnim odnosom do človeka in do njegovega življenja.

10 O pomenu upoštevanja osebne perspektive zarodka gl. Schockenhoff 2013, 444; Globokar 2016, 328. 


\section{Sklep}

Z vidika (moralne) slovnice sodobne zahodne družbe liberalna evgenika nosi v sebi "protislovje«: po eni strani jo podpira načelo radikalne avtonomnosti/»svobode» človeka, po drugi strani pa prakticiranje liberalne evgenike pomeni grožnjo prav temeljnemu gradniku slovnice zahodne družbe: vzajemnemu pripoznavanju oziroma spoštovanju njenih članov kot enakopravnih in avtonomnih oblikovalcev in določevalcev svojega življenja. To pripoznavanje se opira (tudi) na vrednoto avtentičnosti (ki je množični ideal sodobne zahodne družbe (Taylor 2000; 2007, 473504; Žalec 2019). ${ }^{11}$ Prakticiranje liberalne evgenike ogroža spoštovanje drugega ali samega sebe (če sem bil predmet liberalne evgenike) kot avtentičnega in kot avtonomnega oblikovalca in določevalca svojega življenja. Sestavni del tega, da je nekdo spoštovan kot avtonomni oblikovalec svojega življenja, je, da je vprašan za pristanek glede stvari, ki bistveno in nepovratno, nepopravljivo določajo njegovo življenje. Tega pri liberalnoevgeničnih prenatalnih posegih ni moč storiti. Poleg tega pa nimamo zadostne verjetnosti, kaj šele zanesljivosti, kaj nam bi ta nerojena oseba odgovorila, razen morda takrat, kadar bi se izognili zelo velikemu in nedvomnemu trpljenju, ki ga lahko z gotovostjo napovemo (Habermas 2003, 96). Bistveno poseganje $v$ življenje osebe brez njenega pristanka pa je $v$ nasprotju $z$ moralno slovnico sodobne zahodne družbe. Vsekakor bi prakticiranje liberalne evgenike in podobnih reči vneslo v družbo velike razlike in (s tem) napetosti. Zato se morajo ta vprašanja reševati na ravni in po poti družbene razprave, v kateri lahko sodelujejo vsi, in se morajo zakonsko urediti. Prenatalni genetski posegi nikakor ne smejo biti prepuščeni (samo)volji, moči in (z)možnostim posameznikov, ki bi si takšne posege lahko privoščili.

11 Vključenost in sprejetost sta tesno povezani s človekovim polnim in avtentičnim bivanjem. Tomaž Erzar je v zvezi z mozaikom p. Marka Rupnika zapisal: „Na drugi strani je obraz brata, ki živi polno življenje in je v celoti lahko on sam, ker je v celoti sprejet tak, kot je." (Erzar 2019, 12) Liberalna evgenika pomeni zavrnitev posameznika takšnega, kakor je. Zavest o tej zavrnitvi lahko resno načne njegovo duševno zdravje, njegovo samopodobo, psihološko trdnost, samozavest in samozaupanje in (s tem) njegov občutek osebne (enako)vrednosti in avtonomnost. To ni v skladu z držo ljubezni, saj biti ljubljen pomeni prav to: biti sprejet takšen, kakor si. Ljubezen je veselje nad ljubljenim bitjem, takšnim, kakor je. Ljubezen vključuje sprejemanje drugega kot drugega, liberalna evgenika pa z drugim kot drugim ni zadovoljna, ampak ga "popravi« v skladu s predstavami drugih oseb (staršev) o tem, kaj je dobro (za poseganca). Poseganec lahko (kot posledica tega) privzame držo, da (tako ali tako) ni avtor svojega življenja, ali pa si (prav zaradi zavrnitve) goreče želi potrditve od drugih (da je (sedaj) vendarle sprejet). Tako postane negativno odvisen od mnenja, presoje in želja drugih glede sebe, svoje vrednosti in svojega ravnanja, od odziva in potrditve drugih itd. Podobne stvari veljajo glede splava. Tudi pri splavu govorimo o zavrnitvi, o odločitvi drugih, kako ni dobro ali prav, da bi zarodek (pre)živel. Zavest, da je bil nekdo zavrnjen (kot takšen, kakor je), z namenom splava ali liberalnoevgeničnimi posegi, lahko pomeni zelo težko breme za posameznika, za njegovo okolje in za odnose z drugimi. 


\section{Reference}

Ambrozy, Marian, Roman Králik and José García Martín. 2017. Determinism vs freedom: Some ethics-social implications. XLinguae 10 , št. 4:48-57.

Arendt, Hannah. 1996. Vita activa. Prev. Vlasta Jalušič. Ljubljana: Krtina.

- - - 2003. Izvori totalitarizma. Prev. Zdenka Erbežnik idr. Ljubljana: Študentska založba.

Binetti, Maria in Martina Pavlíková. 2019. Kierkegaard on the reconciliation of conscience. XLinguae 12, št. 3:192-200.

Böckenförde, Ernst-Wolfgang. 1976. Die Entstehung des Staates als Vorgang der Säkularisierung«. V: Staat, Gesellschaft, Freiheit, 42-64. Frankfurt na Majni: Suhrkamp.

Erzar, Tomaž. 2019. Trije povezovalni momenti v terapevtskem procesu odpuščanja in krščanski model odpuščanja. Bogoslovni vestnik 79, št. 1:9-16. https://doi.org/10.34291/bv2019/01/ erzar

Galston, William A. 2008. Liberalni nameni: dobrine, vrline in raznolikost v liberalni državi. Prev. Slavica Jesenovec Petrović in Borut Petrović Jesenovec. Ljubljana: Študentska založba.

Globokar, Roman. 2016. Etični razmislek o žrtvovanju človeških zarodkov $v$ znanstvene namene. Bogoslovni vestnik 76, št. 2:313-332.

Habermas, Jürgen. 2003. Die Moderne - ein unvollendetes Projekt. V: Zeitdiagnosen: Zwölf Essays 1980-2001, 7-48. Frankfurt na Majni: Suhrkamp.

- - - 2005. Prihodnost človeške narave: Verjeti in vedeti. Prev. Mojca Dobnikar. Ljubljana: Studia humanitatis.

- - . 2007. Med naturalizmom in religijo: Filozofski sestavki. Prev. Božidar Debenjak. Ljubljana: Sophia.

Habermas, Jürgen, in Joseph Ratzinger. 2005. Dialektik der Säkularisierung: Über Vernunft und Religion. Freiburg: Herder.

Ibragimov, Ibragim D., Badma V. Sangadzhiev, Sergey N. Kashurnikov, Ivan A. Sharonov in Julia A. Krokhina. 2018. Machiavellianism and manipulation: from social philosophy to social psychology. XLinguae 11, št. 2:404-419.

Janez Pavel II. 2005. Memory \& Identity: Personal Reflections. London: Weidenfeld \& Nicolson.

Jonas, Hans. 1984. The Imperative of Responsibility: In Search of an Ethics for the Technological Age. Chicago: The University of Chicago Press.

Junker-Kenny, Maureen. 2011. Habermas and Theology. London: T\&T Clark International.

Kierkegaard, Søren. 1987. Bolezen za smrt: krščan- ska psihološka razprava za spodbudo in prebujo; Trije spodbudni govori. Prev. Janez Zupet. Celje: Mohorjeva družba.

- - . 2003. Ali-ali. Prev. Primož Repar. Ljubljana: Študentska založba.

Klun, Branko. 2013. Vprašanje obupa in samomora pri Kierkegaardu. Bogoslovni vestnik 73, št. 3:367-376.

Kondrla, Peter, in Martina Pavlíková. 2016. From Formal Ethics to Existential Ethics. European Journal of Science and Theology 12, št. 3:101111.

Králik, Roman, in Torok L'uboš. 2016. Concept of Relationship God-Man in Kierkegaard's Writing: What We Learn from the Lilies in the Field and from the Birds in the Air. European Journal of Science and Theology 12, št. 2:65-74.

Máhrik, Tibor. 2018. Truth as the key metaethical category in Kierkegaard. XLinguae 11, št. 1:40-48.

Martín, José García, Monica Ortiz-Cobo in Peter Kondrla. 2019. Ethics, motivation and education from the perspective of Søren Kierkegaard's philosophy. XLinguae 12, št. 4:183-191.

Malović, Nenad. 2015. Suvremeno poimanje slobode i njegove posljedice za kršćansku praksu. Bogoslovska smotra 85, št. 4:941-956.

Morris, Theresa. 2013. Hans Jonas's Ethic of Responsibility: From Ontology to Ecology. New York: SUNY.

Pagon, Neda. 2005. Habermasova kritika liberalne evgenike. V: Habermas 2005, 121-136.

Petkovšek, Robert. 2019. Teologija pred izzivi sodobne antropološke krize: preambula apostolske konstitucije Veritatis gaudium. Bogoslovni vestnik 79, št.1:17-31. https://doi. org/10.34291/bv2019/01/petkovsek

Platovnjak, Ivan. 2017a. Goodness and Health: The Culture of Goodness. Synthesis Philosophica 63, št. 1:79-92. https://doi.org/10.21464/ sp32106

- - - 2017b. Vpliv religije in kulture na duhovnost in obratno. Bogoslovni vestnik 77, št. 2:337-344.

Reder, Michael, in Josef Schmidt. 2010. Habermas and Religion. V: Jürgen Habermas et al. An Awareness of What is Missing: Faith and Reason in a Post-Secular Age. Cambridge \& Malden: Polity Press.

Roberts, Robert C. 1995. Kierkegaard, Wittgenstein, and a Method of »Virtue Ethics«. V: Kierkegaard in Post/Modernity, 142-166. Ur. Martin J. Matuštík in Merold Westphal. Bloomington, Indianapolis: Indiana University. 
Sartre, Jean-Paul. 1968. Izbrani filozofski spisi. Prev. Mirko Hribar. Ljubljana: Cankarjeva založba.

Schockenhoff, Eberhard. 2013. Etika življenja: temeljna načela in konkretna vprašanja. Prev. Jože Urbanija in Gregor Lavrinec. Celje: Celjska Mohorjeva družba.

Strahovnik, Vojko. 2017. Religija, javni prostor in zavzetost v dialogu. Bogoslovni vestnik 77, št. 2:269-278

- - -. 2018. Spoznavna (ne)pravičnost, krepost spoznavne ponižnosti in monoteizem. Bogoslovni vestnik 78, št. 2:299-311.

Taylor, Charles. 2000. Nelagodna sodobnost. Prev. Bojan Žalec. Ljubljana: Študentska založba.

- - - A Secular Age. Cambridge, MA: The Belknap of Harvard University Press.

Tavilla, Igor, Roman Kralik, Carson Webb, Xiamgdong Jiang in Juan Manuel Aguilar. 2019. The rise of fascism and the reformation of Hegel's dialectic into Italian neo-idealist philosophy. XLinguae 12, št.1:139-150.

Tavilla, Igor, Roman Králik in Marie Roubalová. 2019. Abraham and the tortoise: eleatic variations on Fear and Trembling. XLinguae 12, št. 4:219-228.

Valčo, Michal. 2016. Kierkegaard's Sickness Unto Death as a Resource in Our Search for Personal Authenticity. European Journal of Science and Theology 12, št. 1:97-105.

Valčo, Michal, in Peter Šturák. 2018. The »Relational Self«: Philosophical-Religious Reflections in Anthropology and Personalism. XLinguae 11, št. 1:289-299.

Žalec, Bojan. 2008. Izvori pravega liberalizma: o moralnih in religioznih temeljih dobre družbe in države. V: Galston 2008, 425-462.

- - - 2009. Gorečnost naših dni: na poti k svetovni kulturi in civiliziranosti. V: Peter Sloterdijk. Politično-psihološki poskus, 335-347. Prev.
Slavo Šerc. Ljubljana: Študentska založba.

- - - 2010. Človek, morala in umetnost. Ljubljana: Teološka fakulteta.

- - . 2011. Personalism, Truth and Human Rights. V: Humanity after Selfish Prometheus: Chances of Dialogue and Ethics in a Technicized World, 29-41. Ur. Janez Juhant in Bojan Žalec. Zürich: Lit.

- - - 2013. Genocide as social death: a comparative conceptual analysis. Anthropological notebooks 19, št. 2:57-74.

- - . 2015. Genocide, Totalitarianism and Multiculturalism: Perspectives in the Light of Solidary Personalism. Zürich: Lit.

- - - 2018a. Kierkegaard's Method: Edification and Moral Grammar of Christian Virtues. European Journal of Science and Theology 14, št. 6:47-54.

- - . 2018b. Kierkegaardova duhovna edukacija i okrepljenje. V: Religija između hermeneutike $i$ fenomenologije: zbornik u čast prof. $d r$. sc. Josipu Osliću povodom 65. godine života, 187201. Ur. Ivan Dodlek, Nenad Malović in Željko Pavić. Zagreb: Katolički bogoslovni fakultet: Kršćanska sadašnjost.

- - . 2018c. Arendt and refugees (at present): personalist anthropological foundations of the ethics of refugeeism. Poligrafi 23, št. 91/92:207-225; 232, 238.

- - - 2019. Charles Taylor on Religion in a Modern Cultural Frame: Secularity and Authenticity. V: Religion as a Factor of Intercultural Dialogue, 39-48. Ur. Robert Petkovšek in Bojan Žalec. Zürich: Lit.

Žižek, Slavoj. 2009. First as Tragedy, Then as Farce. London, New York: Verso. 